\title{
REMEMBERING AND COMMEMORATING THE THEOLOGICAL LEGACY OF JOHN G. LAKE IN SOUTH AFRICA AFTER A HUNDRED YEARS
}

\section{Marius Nel}

Research Unit of the Faculty of Theology, North-West University, South Africa

nel.marius1@gmail.com

\section{ABSTRACT}

John G. Lake visited South Africa in 1908 as part of a missionary team with the aim to propagate the message of the baptism of the Holy Spirit as experienced at the Apostolic Faith Gospel Mission in 312 Azusa Street, Los Angeles under the leadership of William Seymour, son of African-American slaves. Lake's missionary endeavours that ended in 1913 established the Apostolic Faith Mission of South Africa and eventually also the African Pentecostal churches ('spiritual churches', 'Spirit-type churches', 'independent African Pentecostal churches' or 'prophet-healing churches') constituting the majority of so-called African Independent/Initiated/Instituted (or indigenous) churches (AICs). This article calls for remembering and commemorating Lake's theological legacy in South Africa in terms of these two groups of churches.

Keywords: John G. Lake; Pentecostal; African Pentecostal churches; Apostolic Faith Mission of South Africa; divine healing; holiness

\section{UNISA $\cong$}

Studia Historiae Ecclesiasticae Volume 41 | Number 3 | 2015 pp. $147-170$
DOI: http://dx.doi.org/10.17159/2412-4265/2015/400 Print ISSN 1017-0499 | Online 2412-4265 (C) 2015. Studia Historiae Ecclesiasticae 


\section{INTRODUCTION}

The sixteenth century saw the Protestant Reformation that changed the accepted understanding of the Christian church and its role in society in the Western world and gave the Bible back to all believers. The twentieth century saw a second reformation that might have had a greater impact on the worldwide church than that of the Protestant Reformation (Botha 2007, 295). ${ }^{1}$ The Pentecostal movement started from humble beginnings in 1901 and 1906 and developed into perhaps the most significant religious movement in the twentieth century, growing at a rate of 52000 a day or 19 million a year, as estimated by David Barrett (1998, 50). In 1993 the number of Pentecostals and charismatics exceeded 420 million people (Synan 2006, 1), and in 2006 the number exceeded 580 million (Blumhofer 2006, 21). ${ }^{2}$ 'At the current rate of growth, some researchers predict there will be 1 billion Pentecostals by 2025, most located in Asia, Africa, and Latin America' (McClung 2006, 35). ${ }^{3}$

The international Pentecostal movement originated partly in a black church in Azusa Street, Los Angeles, the American Jerusalem, ${ }^{4}$ led by William Seymour, son of African slaves (Anderson 2012c, 186). Azusa Street was a multiracial church although white people attended a church led by an unpretentious black man (Lovett $1975,136)^{5}$ who had earlier suffered the ignominy of sitting outside the door of the class room of Charles Parham's Bible school in Houston (Anderson 1997, 2). People

1 Botha $(2007,1)$ argues for a second reformation, 'even greater than the Protestant Reformation of the 16th century' that has had an 'even greater impact on the church in general than that of the earlier Reformation.' It is not only a continuation of the Protestant Reformation, but a new Reformation in itself, with a far greater impact than the Protestant Reformation (Botha 2007, 1-2). $\mathrm{He}$ is referring to the Pentecostal-charismatic movement that started with the Azusa Street revival in 1906.

2 By 1910, about 80 per cent or more of the world's Christians were found in the global North. Today, about 63 per cent of global Christians are found in the southern continents (Ma 2013. 65). In 1910, 66.3 per cent of Europe was Christian; today, it is only 25.9 per cent (Joubert 2013, 114). On the other hand, Christianity grew in sub-Saharan Africa from 9 per cent in 1910 to 63 per cent in 2010 (Joubert 2013, 115).

3 The movement started with classical Pentecostals in Parham's Bible School and at Azusa Street; was perpetuated in the charismatic renewal of the 1960s with Dennis Bennett, Kevin Ranaghan, and Kathryn Kuhlman in Van Nuys, California, only a few kilometres north of Azusa Street (Harper 2008, 108; Tickle 2012, 67-69); and invigorated by the third-wave neo-charismatic movement of Peter Wagner and John Wimber (Gabriel 2012, 150-154; Synan 2001, 177-232). Cp. Cox 1995, 20, 23-25, 34-42.

4 Frank Bartleman wrote about the revival in Way of Faith, a Holiness periodical published in Columbia, South Carolina, in August 1906, 'Pentecost has come to Los Angeles, the American Jerusalem.' He also described how 'strong men lie for hours under the mighty powers of God, cut down like grass' (quoted in Pete 2015, 1).

5 'Such radicality and revolutionary nature of the revival both repulsed and fascinated its critics, both secular and Christian' (Tan-Chow 2013, 45). 
flocked to Azusa Street to 'receive the Spirit' ${ }^{6}$ and they left with the message of 'Pentecost' and an evangelistic zeal to share it with the world, reaching fifty nations within something more than two years (1906-1908) (MacRobert 1988, 56, 81).

John G. Lake was at Azusa Street in 1907 with Seymour and other Pentecostal leaders (Lake 1981, 32) ${ }^{7}$ and he led a party consisting of Thomas Hezmalhalch and others, with the purpose to bring the message of 'Pentecost' to South Africa. He revisited Azusa Street on at least one occasion to report to Seymour about the progress of his Pentecostal mission in South Africa that started in 1908 (Anderson, 1997:3; Lake 1981, 32). When Lake left South Africa in 1913, never to return, he left behind what would eventually become two of the most important Pentecostal groups in South Africa, the Apostolic Faith Mission of South Africa (AFM of SA) and the Zion Apostolic Church (Anderson 2001, 7). Pentecostal churches were opposed and even actively disenfranchised by the mainline churches in South Africa; however, Pentecostalism today accounts for the vast majority of Christians in South Africa (Anderson 2000, 14; 2001, 27; Nel 2005a, 202-203; 2005b, 130-136). Around half of Southern African Christians today are adherents of the Zionist/Pentecostalist legacy of Lake (Morton 2012, 98). ${ }^{8}$

In this article the theological legacy of John G. Lake is remembered and commemorated in terms of the two church groups that his work left behind, the AFM of SA and those independent African Pentecostal churches that can be referred back to the missionary work of Lake's party.

Before discussing Lake's theological legacy it is necessary to show where he stood in terms of the theological streams that underlie the Pentecostal movement.

\section{Theological roots of the Pentecostal movement}

The Pentecostal movement originated from and was influenced by a diversity of movements such as: i) Pietism with Philip Jakob Spener (1635-1705), August Hermann Francke (1663-1727), and Nikolaus Ludwig von Zinzendorf (1700-1760) as leaders and its emphasis on the spiritual experience of the individual (Walker 1959, 444-454); ii) the First Evangelical Awakening with John Wesley (1703-1791) and Charles Wesley (1707-1788) (Klaus 2006, 2), George Whitefield (1714-1770) and Jonathan Edwards (1703-1758) in the eighteenth century with its emphasis on the necessity that each Christian should experience an inner change of heart

6 'The services [at Azusa Street] centred on baptism of the Holy Spirit and did not involve prayer, singing or sermons in the usual sense' (Hammonds 2009, 7). After 1909 the church went into decline and by 1914 the membership was almost entirely black.

7 After meeting Seymour for the first time in 1907, Lake $(1981,19)$ commented that Seymour had 'more of God in his life than any man I had ever met.'

8 "The "Pentecostalization" of African Christianity can be called the "African Reformation" of the twentieth century, which has fundamentally altered the character of African Christianity, including that of the older churches' (Anderson 2012a, 29). 
leading to holiness apart from repentance (Latourette 1975, 1023-1029); iii) the Second Evangelical Awakening with Charles G. Finney (1792-1875), Dwight L. Moodie (1837-1899), and R.A. Torrey (1856-1928) with its emphasis on personal repentance leading to a life of sanctification as the experience of the baptism with the Spirit (Dayton 1987, 155; Latourette 1975, 1253-1255); iv) the holiness movement originating from Wesley's Methodism with its theological emphasis of repentance as a crisis experience, sanctification as a definite work of grace, ${ }^{9}$ divine healing, and premillennialism and its apocalyptic eschatology (Burger 1987, 66; Dayton 1987, 159; Kelsey 1964, 72), with the Keswick Convention founded in 1875 which focussed on a second blessing to deal with sin in one's personal life (Anderson 2012b, 128; Harper 2008, 107; Klaus 2006, 2) and the Salvation Army supporting the holiness ideals, and Andrew Murray (1828-1917) playing an important role in propagating it in South Africa (Du Plessis 1919, 24-63); Edward Irving (1792-1834) and the Irvingites (Dallimore 1983, 137); v) the faith healing movement in America under leadership of Ethan O. Allen (1813-1903), Charles Cullis (1833-1892) (Chappell 1988, 358; Cullis 1983, 67-100; Dayton 1987, 127-130) and John Alexander Dowie (1847-1907) and his Zion Christian Church in Zion.

Synan $(1997, x)$ traces the origins of the Pentecostal baptism back to the rite of confirmation, a practical and sacramental laying of hands by the bishop in the Western church that conferred the Spirit as a second blessing. In later centuries in the monastic and mystical traditions the rite was perpetuated by stressing a 'deeper' or 'higher' Christian life beyond the confines of nominalism that characterised the majority of Christians (Synan 1997, x). Neither the full depth of a relationship with God nor all the gifts of the Spirit were received at conversion or confirmation, leaving room for a second, deeper experience that Pentecostal people would call the second blessing, of the baptism with the Spirit (Clark and Lederle 1989, 47). Upon this seminal idea, John Wesley founded his holiness movement with its pursuit of Christian perfection or entire sanctification (Harper 2008, 105) as a strong reaction against the severe Calvinism of his day with its teaching of a predestined select few (Synan 1997, 2) while Wesley's Methodism emphasised that salvation was for all and the accompanying proof or evidence of salvation is a crisis experience at the moment of conversion as well as a second blessing where the believer is cleansed from a residue of sin which remained because of Adam's sin, inspiring the believer to live in victory over conscious wilful sin (Wesley 1993, 35). Wesley's theology was Arminian with a strongly perfectionistic spirituality and lifestyle (Synan 1971, 15). This subsequent experience Wesley ([1766] 2012, 87) calls 'entire sanctification', 'perfect love', 'Christian perfection' or 'heart purity' in his tract, A plain account of Christian perfection. Wesley's colleague, John Fletcher (1729-1785) in Checks to Antinomianism $(1820,101)$ coined the term 'baptism in the Holy Spirit' to refer to

9 The argument used was that the power and gifts of the Holy Spirit can only operate in purified vessels (Wenk 2010, 109). 
the 'second blessing. ${ }^{10}$ Methodism spread in America with a massive revival in New York in 1858 and the national camp meetings for the promotion of holiness between 1867 and 1883 organised by Phoebe Palmer (1807-1874), John Inskip (1816-1884), Alfred Cookman (1828-1871) and William Osborn (1832-1902) of the Methodist Church and Methodist Episcopal Church, and the formation of the National Holiness Association. The holiness movement within the Methodist tradition started to receive severe opposition in the mid-1880s, and in 1894 the General Conference of the Methodist Episcopal Church South rejected it and effectively ended the holiness movement in the Methodist Church. By 1900 at least 23 holiness denominations had emerged with their peculiar view of a second blessing related to a baptism of the Spirit with accompanying physical manifestations and leading to a life of holiness.

In 1895 Charles Fox Parham (1873-1929), a minister of the Methodist Episcopal Church, dissociated himself from the church because of its decision about holiness. ${ }^{11}$ The divine healing home that he established in Topeka in Kansas led to the Bethel Bible School that he started in 1900 with 40 students. His theology was influenced by the holiness tradition of Wesley, divine healing theology of John A. Dowie, and Spirit theology of A.B. Simpson's Christian and Missionary Alliance and Frank Sandford's The Holy Ghost and Us Church (Cauchi 2004). ${ }^{12}$ At some stage he and his students investigated biblical evidence for the second blessing (Synan 1997, 91) and they concluded that the second blessing had to be supplemented with a third experience, the Spirit baptism, and that there would be definite proof or confirmation of the experience in the form of speaking in tongues, a conclusion already reached in the 1890s by B.H. Irwin of the Fire Baptized Holiness Church (Synan 2001, 34). In this way Parham formalised the doctrine of speaking in tongues as the distinctive

10 John Fletcher was the vicar of Madeley and Wesley's designated successor, although in the event he pre-deceased him. Wesley described the 'moment' always as entire sanctification, but Fletcher started using new language, about 'receiving the Holy Ghost,' with Wesley disagreeing and objecting to this term, although the disagreement did not affect their partnership (Harper 2008, 106). Wesley answered Fletcher that he believed that all Christians received the Holy Spirit when they were justified (Dayton 1987, 63). Dayton $(1987,93)$ refers to the 'shift to Pentecostal vocabulary' and the result that it brought to the fore various pneumatological themes. Wesley seldom, if ever, mentioned the Acts of the Apostles in his sermons and writings while Fletcher quoted from Acts more than any other book in the New Testament. Acts came to the centre stage in the Pentecostal and charismatic movements (Dayton 1987, 49-54; Stronstad 2012, 19).

11 Richie (2007, 138-139) calls Parham autocratic and idiosyncratic, although he profoundly impacted Pentecostalism to this day. He was committed to the absolute uniqueness and necessity of Jesus Christ as Lord and Saviour.

12 Writing in March 1899, Charles Parham (1902, 27-28) testifies, 'The Holy Ghost and fire, the real power of Pentecost, came in, and I have never had a pain or ache since, while hundreds have been healed in answer to the Pentecost prayer of the Holy Ghost through me.' 
characteristic of the modern Pentecostal movement (Botha 2007, 299). ${ }^{13}$ On 1 January, 1901 Agnes Ozman, a female student, started speaking in Chinese after Parham laid his hands on her and she could not speak English for three days. Speaking in tongues was perceived as a supernatural impartation of existing languages (xenolalia) with the express purpose of world evangelisation (Synan 2006, 4). Most of the other students shared in the experience and it was widely reported. Parham closed his school and spread the news of the third blessing on a revival tour across the Midwest. ${ }^{14}$

In 1905 he opened another Bible school in Houston, Texas with 25 students. A poor African-American student with one eye applied to attend classes. Parham allowed William Joseph Seymour (1870-1922) to monitor the classes from the hallway as it was illegal for blacks to attend classes along with white students (Synan 1997, 93). After a few months he had accepted the doctrine of speaking in tongues as evidence of Spirit baptism although he had not shared in the experience. A small independent holiness assembly invited Seymour to become their pastor and in his

13 Friesen's $(2009,43)$ remark is important, that Parham's contribution to Pentecostalism was not only the insight that the speaking in tongues is the initial evidence of Spirit baptism and an irrefutable proof that one was baptised in the Spirit, but his contribution resides at the level of hermeneutics in the way he read and applied the book of Acts to his day. He was the first to postulate that the experience of speaking in tongues by the first disciples on the Day of Pentecost was meant to be repeated in the lives of modern Christians (Friesen 2009, 54). It was his hermeneutic that was taken up by later Pentecostals at Azusa Street and formed a basis for the movement's emphasis on foreign missions (Friesen 2009, 55), although it can be argued that Parham never seemed to express a desire for the heathen converts of Spirit-baptised missionaries to be baptised in the Spirit. On the contrary, Parham's acceptance of the racist Anglo- or British-Israelite theory that teaches that the 10 lost tribes of Israel were actually the ancestors of Anglo-Saxon people, allowed him to retain salvation for the descendants of the ancient covenantal people at the cost of the 'heathen' (Richie 2007, 144-145). Goff $(1988,173)$ identified 'three theological planks' which Parham joined to form the first distinctly Pentecostal theology: tongue speaking as the initial evidence of Holy Spirit baptism; Spirit-filled believers as the 'sealed' bride of Christ; and xenoglossic tongues as the tool for a dramatic end-time revival.

14 Parham embraced what he believed was the 'Apostolic Faith' of the early church that had been restored in his Bible school with the main end, to bring in the end-time harvest of souls. Through the outpouring of the Spirit (Joel 2:28-29) God miraculously had begun to bestow unlearned languages on Spirit-baptised believers to preach the Good News to the nations, just as it happened on the Day of Pentecost nineteen hundred years earlier (McGee 2006, 100; McGee 2007, 1). The anticipated preaching in newfound languages disappointed the earliest missionaries when they arrived in their mission fields and early Pentecostals had to return to the New Testament to discover that tongues largely serve as an avenue of prayer and praise (Anderson 1979, 89-92; McGee, 2007, 1; Synan 1997, 89-92, 101-102; Wacker 2001, 44-51). It seems that Pentecostals said little about this transition, as though they might have judged it to be a chapter in their pilgrimage best to be forgotten (Gee 1949, 11-19). Speaking in tongues led to new levels of joy and love; heightened sensitivity to the promptings of the Spirit; the manifestation of charismatic gifts; invigorated boldness to witness; an ability to cast out demons; and the experience of an acquired holiness (Haywood, 1908:3; Taylor 1907, 128). Holiness believers had similarly portrayed the effects of their encounter with the Spirit, but what distinguished and alienated Pentecostals was the central role of speaking in tongues that produces this bliss (Taylor 1907, 39-59; Wacker 1999, 23-49). 
first sermon in March 1906 he shared his new doctrine about Spirit baptism. The leaders of the congregation decided that his teaching was not in line with accepted holiness traditions and they barred him from the church. He continued preaching from the house where he stayed in Bonnie Brae Street and on 9 April 1906 he and seven of his listeners started speaking in tongues. Soon crowds gathered to see the spectacle and Seymour was forced to relocate to a larger facility, an abandoned African Methodist Episcopal Church at 312 Azusa Street (Anderson 2012c, 187). Here services were held for three and a half years three times daily, seven days a week. Seymour reported about the services in the Apostolic Faith, a magazine of which 50000 copies were sent free to interested parties. ${ }^{15}$

Several holiness churches became Pentecostal while retaining most of their perfectionist teachings, such as the Church of God in Christ (originating in 1897), the Pentecostal Holiness Church (1898), the Church of God (1906), and other smaller groups. They had formed as 'second blessing' holiness denominations and simply added the baptism in the Spirit with glossolalia as 'initial evidence' of a 'third blessing' (Synan 1997, 51).

Azusa Street combined elements of white holiness religion with AfricanAmerican worship styles that had developed since the days of chattel slavery in the South. Appalachian whites and Southern blacks shared the expressive worship styles at Azusa Street and created a new indigenous form of Pentecostalism with tongues and other charisms, shouting and dancing that proved attractive to disinherited people (Anderson 1979, 69-70). The mission had a multi-racial, multi-ethnic character with Ethiopians, Americans, Chinese, Indians and Mexicans worshiping together (Editorial, 1906, 1).

\section{John G. Lake's theological stance ${ }^{16}$}

Lake (born 18 March 1870 in Ontario, Canada, died 16 September 1935) was converted in 1886 in a Salvation Army meeting, and was ordained and admitted to the Methodist ministry in Chicago in October, 1891 (Susanto and Theron 2008, 173-174). He shared the primitivistic motif with its concern for the restoration of the

15 Parham visited Azusa Street in October 1906 in order to 'control' the Azusa Street revival and was disgusted by the interracial fellowship, what he called 'hypnotism' and the 'freak imitation of Pentecost' (Anderson 2012c, 188). 'Horrible, awful shame!' he responded and adding that it 'makes me sick at my stomach...to see white people imitating unintelligent, crude Negroism of the Southland, and laying it on the Holy Ghost' (Anderson 1979, 190). Parham was rejected by Azusa Street as an overseer, was never reconciled with Seymour, and fell into obscurity when he was arrested on unproven charges of sodomy a year later. 'His role in the formation of the classical Pentecostal doctrine of baptism in the Spirit was all but forgotten as Pentecostal leaders dissociated themselves from him' (Anderson 2012c, 188).

16 Extensive documentation about Lake can be found at the Flower Pentecostal Heritage Center, Springfield, Missouri. Some of the material has been reprinted, such as in Lake, 1994; Liardon, 2005; Lindsay, 1972; and Reidt, 1989. 
apostolic faith (Dayton 1987, 41) and the sentiment for holiness and perfection with the holiness movement. Lake emphasised the holiness teaching of the Methodists (Dayton 1987, 38-40), divine healing ${ }^{17}$ and pre-millennialism ${ }^{18}$ as he learnt it from Dowie's Zionism (Anderson 1979, 74; Klaus 2006, 2; Morton 2012, 106-107) and an Arminian gospel of free will (Dayton 1987, 63-64, 153, 155).

He utilised a distinctively Pentecostal manner of appropriating the Scriptures. In contrast to magisterial Protestantism which tends to read the New Testament through Pauline eyes, explains Dayton $(1987,23)$, Pentecostalism reads the rest of the New Testament through Lukan eyes, especially with the lenses provided by the Acts of the Apostles. ${ }^{19}$ Luke in his Gospel and in Acts provides narratives of events that Pentecostal people believe are to be duplicated and expected in contemporary times (Welch 1972, 28). Lake expected that as in the early church, the modern believer becomes a disciple of Christ, receives the fullness of the Spirit's baptism, becomes part of the healing ministry, and expects the second coming of Jesus as imminent (Myland 1910, 91; Reidt 1989, 18). Like R.L. Parham (1902, 44-45), Lake believed that miracles of healing are not only part of salvation and relief brought to humanity in Christ, but are also a sign of reassurance to the believer and a witness to the unbeliever (Dayton 1987, 24; Reidt 1981, 18-19).

Lake held a restorationist motif in common with other Pentecostals (Land 1993, 7) in contrast to classical Protestantism that argues that the charismata and supernatural working of the Spirit ceased with the close of the apostolic era (as e.g. Warfield 1918, 5-6 argues). Lake $(1971,34)$ argued that the nature of the apostolic church of the first century is normative for the church throughout the ages because God is unchangeable. The charismata and divine healings reported in the New Testament have permanent validity for believers of all ages (Lindsay 1949, 125). Because God is unchangeable the modern church should reflect the nature of the apostolic church (Lindsay 1978, 21).

After a short stint as pastor of a church in Peshtigo, Wisconsin, Lake left the ministry to found a newspaper and set up a real estate business before moving in 1904 to Chicago where he bought a seat on the Chicago Board of Trade (Reidt 1989, 13-14). In 1898 he took his sickly brother to John Alexander Dowie for prayer at Dowie's Healing Room in Chicago where he was instantaneously healed (Burger 1997, 176). Lake then prayed for his sick wife and when she was healed he started with

17 Dowie radicalised holiness teachings, extracted the healing doctrines from their holiness context and gave them a slightly different theological grounding, in Dayton's $(1987,136)$ opinion. Healing doctrines were widespread before Dowie but Dowie influenced Lake's teaching of divine healing to a large extent, even in the preference for the term 'divine healing' over against 'prayer healing' or 'faith healing.'

18 However, Wesley can also be seen as one of the pre-millennial antecedents (West 1894). Anderson $(1979,5)$ argues that pre-millennialism is in fact the integrating core of the Pentecostal message.

19 Cf. Mittelstadt (2010) for a discussion of the history and trajectory of Pentecostal contributions to Luke-Acts research. McQueen (2009, 38-40) develops a Lukan pneumatology. 
healing meetings in the Chicago area. By 1901 he moved north to Zion City, Illinois, where Dowie had established his ministry headquarters (Susanto and Theron 2008, 174). There Lake studied divine healing, until 1904 (Copeland 1994, xx). During the later months of 1906, Parham held revival services in Zion City that attracted Lake and his friends. Approximately 3500 Zionists accepted Parham's message and were baptised with the Spirit (Parham 1930, 148-160, 171-177). ${ }^{20}$ Parham left Zion City for good when the municipal water tower collapsed on top of his revival tent. His followers experienced opposition from Dowie's successor, W.G. Voliva. Tom Hezmalhalch, who arrived in Zion City shortly after Parham's departure, played a considerable role in stabilising the followers of Parham when he invited William Seymour to visit the city (Morton 2012, 105).

During October 1907, Lake and Hezmalhalch ministered to an invalid woman in her home and while Hezmalhalch was talking to the woman, Lake was baptised in the Spirit. As a result, 'I found that my life began to manifest in the varied range of the gifts of the Spirit. Healings were of a more powerful order. My nature became so sensitised that I could lay my hands on any man or woman and tell what organ was diseased, and to what extent' (Copeland 1994, xxi). Lake sold his business interests and disposed of his wealth and possessions in imitation of George Muller and Hudson Taylor (Reidt 1989, 14; Tannenberg 1999, 12), and began seeking God's purpose for his life (Lindsay 1976, 34). ${ }^{21}$ At the end of 1907 he was instructed by the Spirit to partake in a winter campaign in Indianapolis before leaving for Africa. On 19 April 1908, Lake's party of 17 left for South Africa (Copeland 1994, xxiii). ${ }^{22}$

South Africa at the beginning of the twentieth century was prepared for the Pentecostal message by the lasting influence of Andrew Murray, the work of John. A. Dowie's Zionist missionaries with their message of divine healing and holiness, and the suffering and poverty that followed the Anglo-Boer War (1899-1902), making a proportion of the population receptive to a message of salvation, holiness and hope (Botha 2007, 301-302).

Daniel Bryant, Dowie's missionary who came to South Africa in 1904, had developed the biggest foreign congregation in Johannesburg (Oosthuizen 1987, 14-18; Sundkler 1976, 34-41). Most members of the church were impoverished African peasants, although the assemblies in Krugersdorp and Boksburg had a large contingent of white members (Nel 1996, 247). Bryant contended for Zionist leadership when Dowie died and when he was eclipsed by his hated rival Voliva

20 'From Zion came a host of almost 500 preachers who entered the ranks of the Pentecostal movement, chief of whom was John G. Lake' (Synan 1997, 138).

21 Morton (2012, 102-104) states the case that Lake's successful business career that he abandoned to pursue the mission to Africa was a myth that he used primarily to create legitimacy for his leadership role in various Pentecostal communities. His argument deserves to be investigated in full.

22 The earliest-known Pentecostal missionary departed from Fargo, North Dakota for South Africa in 1904 (Rodgers 2003, 13-14; Thompson 1937, 8). 
he pulled his South African congregations out of the Zionist church (Morton 2012, 109). When he returned to California, Lake and Hezmalhalch were invited to take the services at his church in Doornfontein, and when the AFM was founded these three Zionist assemblies became the first AFM assemblies (Burger 1987, 173; 1997, 184). ${ }^{23}$

At his first sermon in Johannesburg, Lake preached with the help of an interpreter to a large group of Zulus (Liardon 1996, 179). His services were characterised by signs and wonders of healing and deliverance and soon many people of all races attended it. In early 1909, Lake welcomed Elias Letwaba on the platform during a meeting. He put his arm around Letwaba's neck, kissed him and called him 'my brother,' infuriating many whites in the audience who hissed at and booed Lake (Copeland 1994, xxv). ${ }^{24}$ Lake responded with, 'My friends, God has made of one blood all nations of men. If you do not want to acknowledge them as your brothers, then you'll have the mortification of going away into eternal woe, while you see many of these black folk going to eternal bliss.' Some whites suggested that the 'black devil' should be kicked out but Lake did not back down. With his hand on Letwaba's shoulder he said, 'If you turn out these men, then you must turn me out too, for I will stand by my black brethren' (Copeland 1994, xxv).

Lake's wife died at the end of 1908 (some sources suggest it was later, perhaps only in 1912), and in late 1909 Lake returned to America to attain more workers and money for the South African work. He returned with eight more missionaries and by 1913 , when he returned to America, his missionary work had 1250 part-time preachers, 625 congregations, and 100,000 converts (Copeland 1994, xxvii).

\section{Commemorating Lake in the AFM}

At least three aspects that characterise the contemporary AFM commemorate the theological legacy of Lake. As mentioned, Lake took a stand against the racism latent among whites and suffered criticism for his stance. For many decades the AFM would develop into and exist as four racially divided divisions before it united in 1996 after a long and arduous journey. 'On Good Friday, 5 April 1996, the AFM held a celebration of unity at the Centurion Cricket Stadium where the deputy president, Mr Thabo Mbeki, congratulated the Church on its newfound unity. At this meeting Burger asked forgiveness from Chikane for wrongs done by the Whites in the AFM. Burger did not have the consent of any Council, but felt led by the Spirit to take this step. Tears flowed and members of the AFM were deeply touched by this event

23 Lake and Bryant had had significant dealings in the past as mid-level officials of Dowie's church, and it may be that they orchestrated a take-over of the Johannesburg assembly as Morton (2012, 109) argues, although Lake never mentioned it. The Zionist assembly in Pretoria was not interested in the message of Pentecost that Lake proclaimed (Burger 1987, 168).

24 'He [Lake] had always had a big love for the natives, and a plea for the black man would draw him even sooner than a call from a white congregation' (Burton 1934, 67). 
which was broadcast on national television' (Nel 2012, 135). At last Lake's dream of a multiracial, united church was realised (Molobi and Chikane 2008, 241).

A second aspect of Lake's theological legacy concerns his unrelenting missionary zeal. The Pentecostal movement as well as the AFM started as a missionary movement and throughout the twentieth century it continued to display mission as part of its identity (Botha 2007, 319). 'The strong emphasis on missionary work in the AFM is partly due to the role and influence of Lake' (Burger 1997, 180). The Pentecostal motive for its missiological endeavours remains important; in the words of the Editorial of Pentecost in August 1908,

The Baptism of the Holy Ghost does not consist in simply speaking in tongues...It fills our soul with the love of God for lost humanity, and makes us more than willing to leave home, friends, and all to work in his vineyard, even if it be far away among the heathen... When the Holy Spirit comes into our hearts, the missionary spirit comes with it; they are inseparable.

The AFM derives its name from the church founded by Seymour in Los Angeles in 1906, the Apostolic Faith Gospel Mission Church, emphasising its missiological dimension as integral to the identity of the church (called the apostolic mandate by Anderson 1986, 6) and allowing it to partake in the success of the movement worldwide in reaching people with the Pentecostal message (cp. Asamoah-Gyadu 2002, 17-25; Kärkkäinen 2005, 43-50; Lord 2005, 5). Jenkins (2002, 8) documents that Christianity at the beginning of the twenty-first century had a new centre; it was geographically in the Southern Hemisphere. He postulates further that Pentecostals might possibly be the most successful social movement of the twentieth century that would have ripple effects in the fabric of twenty-first century Christianity, in line with Cox's $(1995,102)$ conclusion that the DNA of Pentecostalism would be central to twenty-first century Christianity.

Thirdly, Lake claimed that 'one of the cardinal teachings of our organisation was the ministry of healing through faith in Jesus Christ, the son of God' (quoted in Van der Spuy, 1985, 71). At the beginning of the nineteenth century medical science was making enormous strides while ministries of healing were non-existent in most mainline or traditional churches (Susanto and Theron 2008, 169). Specifically the Reformed tradition usually did not expect, and even denied, the existence of divine healing and did not accommodate it in its worship and evangelistic services (Barnes and Sered 2005,3). Today the ministry of healing is still relevant and the AFM ministers to many ill people.

\section{Commemorating Lake in the African Pentecostal churches}

The African Pentecostal churches (also called 'spiritual churches' [Baëta 1962]; 'Spirit-type churches' [Daneel 1971, 285]; 'independent African Pentecostal churches' [Hollenweger 1972, 151]; 'prophet-healing churches' [Turner 1979, 97]) constitute the majority of so-called African independent (or indigenous) churches 
(AICs) (Anderson 1997, 1; Asamoah-Gyadu 2015, 2). ${ }^{25}$ These churches are connected to the Pentecostal movement of Western origin and form a prominent part of African Christianity, although their voice is often not heard in ecumenical circles. They emerged when blacks were denied socio-economic, political and ecclesiastical power, with mission churches dominating the 'daughter churches', being dominated by whites exercising paternal control as part of colonial oppression (Comaroff 1985, 172). At the beginning Pentecostal churches were multiracial but especially with Afrikaans-speaking whites taking control, the churches were separated along racial lines and black Pentecostal churches were intentionally disempowered. The African Pentecostal churches became a radical expression of cultural resistance (Comaroff 1985, 166), 'a dissenting discourse' that enabled Southern Africans to mitigate the sufferings imposed by capitalism, colonialism, and apartheid (Comaroff 1985, 112 ), and their ecclesiastical forms masked an often trenchant resistance to the culture of colonial domination (Comaroff 1985, 168; Molobi 2014, 3). Although Anderson $(1991,58)$ criticised their emphasis on the 'power' of the Holy Spirit, African Pentecostals do not see the Spirit as an impersonal, manipulable force. The power of the Spirit is close to the African concept of 'vital force' (Tempels 1959, 44-45), and life and existence are closely bound and inextricably tied up with this power. ${ }^{26}$ Life is from this power; illness and death, as well as poverty and oppression is due to a lack of power. Whenever members of an African society experience problems or they see a foreboding of trouble, they consult the specialists, the traditional diviners and healers who have special powers to discern the wishes of the ancestors and to counteract the evil force of witches and sorcerers. A sorcerer can only harm somebody by gaining access to the victim through their protective ancestors. In times of affliction it is necessary for a diviner to diagnose its cause, and prescribe a relevant ritual or protective medicine or charm to overcome the evil force (Maimela 1985, 70). Western Christianity exported to Africa offered no real alternative solution to the real fears and afflictions experienced by Africans because it did not understand the world view of the African (Maimela 1985, 71). African Pentecostal churches provided a dynamic Christianity that met African needs in this realm with a practice and theology of the Holy Spirit that is at the same time contextualised and biblical (Anderson 1997, 1).

Black people became weak through generations of institutionalised oppression; black theology gave them a vision of black power with its promise of the restoration of their human dignity and self-esteem (Hollenweger 1974, 26). Their call of 'Amandlangawethu!' while raising their clenched fists struck fear in white people's

25 'The AICs are the trail blazers in the reformation of Christianity on the continent, and they did so through a synthesis of biblical thought as they understood it and the African religio-cultural reality' (Asamoah-Gyadu 2013b, 144).

26 South African black theology expressed 'power' as being a relational reality having to do with concrete relations in our socio-historical world (Boesak 1977, 41). 
hearts while it was actually only an expression of blacks' determination to affirm themselves as human beings in the face of white domination, to affirm their dignity and humanity as blacks, a mobilisation of their collective power in order to overcome their suppression (Kritzinger 1988, 44). Amandla means forcefulness, strength and ability (Berglund 1976, 247), a concept comparable to dunamis promised in Acts 1:8 to those upon whom the Spirit comes. For African Pentecostals the power of the Spirit has more than just spiritual significance, as is arguably the case for many Western Pentecostals. An oppressed person faces daily injustices and affronts to personal dignity and the promise of the Spirit's power empowers him/her to face their situation with courage. By embracing the Spirit's power and a new sense of identity as a Spirit-filled believer, African Pentecostals revive their own culture and assert their independence (Martin 2002, 130) ${ }^{27}$ creating churches that are successful and attractive to local indigenous communities because they have grown from their specific historical context. ${ }^{28}$ In their emphasis on the power of the Spirit, African Pentecostals commemorate the most important element of the theological legacy of Lake $(1960,17)$. It is also one of the most important elements of African Pentecostals' success in reaching others. Martin $(2002,142)$ asserts that it is this 'frank acceptance of the power of the old and the embrace of Christian prophylaxis which moved many to secede to the Pentecostals. ${ }^{29}$ 'Pentecostalism is not culturally autonomous, but dynamic, and can adapt to new circumstances...It can function effectively in settings as diverse as a small village hamlet, upper-class neighbourhood living room, a shack in an urban slum, five-star ballroom, or a traditional cathedral...The autochthonous character of Pentecostalism thus enables it to take on the culture of a particular people or group' (Satyavrata 2005, 221). African Pentecostal churches indigenised quickly because there was no dogmatic need to retain a certain fixed set of worship rituals and practices. Local churches developed their own spirituality informed not by theological orthodoxy but by their own particular experiences which were

27 Although the AIC's patriarchal model of leadership views men as the head of their families, and this is not always deserved as when AIC leaders assault their wives, yet social pressure precludes their reporting of their husbands' behaviour to the church authorities or the police (Molobi 2008, 293).

28 'The vitality of Pentecostalism's spirituality and theology in contexts (Asia, Africa, Latin America) where it has learned to lean on insights from indigenous religions without compromising Christian witness, seems to confirm the possibility that Pentecostalism has the potential to develop a truly global Christianity' (Richie 2007, 146)

29 Cp. Charles Parham's $(2000,219)$ remark in 1901 to a newspaper reporter as he reviewed the events of the January 1901 revival at his Bethel Bible School in Topeka, Kansas: 'We wanted power from on high to help save the world. We prayed for it; we received it.' 
informed by their local culture and society (Botha 2007, 305). As a result, African Pentecostal churches each display a distinct local flavour. ${ }^{30}$

Traditional Africa, surrounded by threatening phenomena, reacts by organising the cosmos into explainable phenomena to make order out of the bewilderment. Behind this reasoning lies the supposition that there are no chance occasions or accidents but that reason functions behind every eventuality. The universe and its contents are permeated with 'power' which may be applied with good or evil consequences. African traditional religion may often have resulted in a continual sense of powerlessness and helplessness, a weakness that shows the need for more power to cope. The AICs, and African Pentecostal churches in particular, proclaim a message which aims to provide a qualitatively better alternative, of life-giving power that secures deliverance from evil, and provision in existential every-day needs (Anderson 1997, 2). What Western Christians may observe as 'syncretism' in African Christianity is not necessarily a sign of African Christians' lack of commitment to the gospel but rather an indication of the lack of missionary Christianity to respond to African culturally-based religious aspirations and the success of indigenous churches to meet Africans on their own turf (Ukpong 1984, 510).

Lake visited Azusa Street during 1907, a predominantly black church with a decidedly black way of worshiping and led by the son of African slaves visited by many other white people (Lake 1981, 137). Lake revisited Azusa Street at least once to report on his missionary endeavours in Africa (Lake 1981, 32). When arriving in Africa, Lake's vision was to encounter blacks with his Pentecostal gospel (Burger 1997, 183). However, he was hijacked by the Zionist assembly in Doornfontein with a majority of black and coloured members when he accepted their invitation to preach on 25 May 1908 (Burger and Nel 2008, 55). It was later reported, 'Now these men [Lake and Hezmalhalch] were holding meetings in the slums, and in a native church' (Burger and Nel 2008, 55).

By the time Lake left for America in February 1913, the Central Tabernacle in Bree Street, as well as most other assemblies, was led by whites with Pieter L. le Roux taking the lead as the first South African president (Burger and Nel 2008, 74). Le Roux was also appointed as superintendent of missions but he could no longer manage his own missionary enterprises around Wakkerstroom. Many of his

30 Cf. Althouse $(2009,10)$. Chan $(2000,45)$ outlines Pentecostal liturgical practice where the community of God encounters the Father, Son and Spirit in worship in concrete realities. A spirituality of the Father focuses on the creative God and the ecological value of creation, the social and soteriological God, who sacramentalises created reality. A spirituality of the Son focuses on the salvific and liberating work of Christ and the church's mission as transforming agent in the world. A spirituality of the Spirit lies in the expectation and anticipation for the unknown in the human-divine journey. A Trinitarian spirituality is thus characterised by form and stability, by personal relation with God through Christ, and open to the working of the Spirit in 'signs and wonders' in which the mission of the church is oriented to a critical and constructive engagement in the world (Chan 2000, 49). 
followers founded African Pentecostal churches when he left for Johannesburg (Nel 2005a, 203-205). White Pentecostals in South Africa strongly emphasised personal piety while hiding their racism leading to social sins like excluding blacks from their worship services long before the Nationalist Party would require it (as from 1948). Lake's challenge to a social system based on racism that led to criticism and ostracism was transformed into a bulwark of it (Anderson 1979, 222). Early Pentecostalism's interracial, multi-ethnic composition was in itself a radical criticism of prevailing racial attitudes as well as a radical departure from it. Pentecostalism could and should have been championing for the poor and oppressed as its early adherents came from the dispossessed Africans and poor white Afrikaners staggering from the impact of a crushing defeat at the hands of the mighty British Empire (De Wet 1989, 39). However, leadership in the AFM was kept firmly in white hands (De Wet 1989, 161), leading directly to the eventual separation of the independent Zionist churches from the AFM. Estrangement between black and white Pentecostals occurred over a long period of time, with the earliest recorded secession from the AFM taking place in 1917, when Elias Mahlangu founded the Zion Apostolic Church of South Africa, although at that time many more unrecorded secessions had probably taken place (De Wet 1989, 63) ${ }^{31}$ Edward Lion's Zion Apostolic Faith Mission seceded out of Mahlangu's church in 1920. ${ }^{32}$ Engenas Lekganyane's Zion Christian Church seceded from Lion's Zion Apostolic Faith Mission around 1925, ${ }^{33}$ today forming the two largest AIC's in Southern Africa and one of the largest in Africa (Cochrane 1994, 215-216; Daneel 1971, 300; Sundkler 1976, 65-66). ${ }^{34}$

African Pentecostals' emphasis on the 'power from on high' (Luke 24:49) realised through the Pentecostal experience, is translated by many Africans as God granting the black person dignity, power and liberation. Liberation is interpreted in

31 Morton $(2014,75)$ states the case that Isaiah Mdliwamafaezwe Shembe founded the Ibandla lamaNazaretha (Nazarites) in 1913, not as a unique prophet with a mission to found a church as his believers maintained or as someone who developed his religious ideas autochthonously as most academics maintain, but as a result of his involvement with the AFM in the Orange River Colony and travelling in the company of its leadership on missionary outreaches to Harrismith and Witzieshoek. He derived his sense of divine calling, his wide repertoire of faith healing techniques (including refraining from use of medicine, laying on of hands, expelling demons, and raising the dead), and his conscious reshaping of his autobiography from Lake with his 'American-derived tent revival style.' Shembe also absorbed the rhetorical style of Lake who emphasised prophecies and direct revelation (Morton 2014, 79-87).

32 The chosen name of Lion's church show their obvious desire to maintain continuity with the Azusa Street mission.

33 Anderson $(1992,40-41)$ and Morton $(2012,113)$ calls Lion the mentor of Engenas Lekganyane. Cf. also Haliburton (1976, 64-70).

34 By 1993 the Zion Christian Church (ZCC) claimed to have six million members, making it South Africa's largest Christian denomination (Synan 1997, 138). The church consists of the main ZCC star church and the (dove) splinter group Saint Engenas ZCC (Lukhaimane 1980, 1). In its annual Easter conference at Zion near Polokwane, the church gathers upwards of two million worshippers, the largest annual gathering of Christians on earth (Synan 2006, 6). 
a holistic way from everything that oppresses and demeans personal self-esteem, empowering people to live as equals. 'Black Pentecostalism affirms with dogmatic insistence that liberation is always the consequence of the presence of the Spirit...No man can genuinely experience the fullness of the Spirit and remain a bona fide racist' (Lovett 1975, 140). The God who forgives sin is also concerned with liberating people from the powerlessness of poverty, oppression and all physical afflictions. African Pentecostal churches emphasise divine healing as the practical agency of divine force (Comaroff 1985, 176), in the same manner as Lake did when he connected healing to the atonement (Chappell 1983, 51; Horn 1989, 28-29; Lindsay 1976, 19). It is this message of liberation that makes the Pentecostal churches attractive to Africans. Although early Pentecostals distrusted medical healing, today they recognise that divine healing and medical healing should not be confused, with the latter a gift of God to humanity and therefore appropriate to access, although the need for a divine intervention without medicine remains in many cases (Warrington 2005, 236).

Maimela's $(1985,71)$ remark is relevant, that the greatest attraction of AICs lies in their open invitation to Africans to bring their fears and anxieties about inevitable threatening adversities presumably caused by witches and sorcerers, bad luck, poverty, physical and spiritual illness, and all kinds of misfortune to the church for prayer of liberation. ${ }^{35}$ The Pentecostal message is relevant for such people, with its promise of the power of God that can change any situation because his power is greater than any of the powers that may threaten human existence. Their emphasis on the power of the Spirit distinguishes them from most other churches; they show that a demonstration of the Spirit's power will often convince Africans that God is indeed more powerful than any surrounding evil force, and therefore worthy to be worshiped. In Africa the most-powerful God is worshiped, and he manifests his presence through the Holy Spirit working in the church.

A last remark is necessary; the observation of some that African Pentecostalism has subdued itself to American pressure to emphasise success, prosperity, wealth and health of the Faith movement as basic to the gospel at the expense of the gospel of the cross (Horn 1989, 35-52). However, such an observation does not understand the African world where supernatural evil realities dominate the agenda (AsamoahGyadu 2013b, 155), necessitating frequent prayers for exorcism and healing against the powers that oppress and possess people and deprive them of their health, wealth, and wellbeing (Asamoah-Gyadu 2013a, 44). Poverty and lack of progress are demonically instigated, as part of the African worldview that things do not happen by

35 In the language of Anderson, Venn, Nevius, Allen, and Luce, the characteristics of the New Testament church are those of an indigenous church - a contextual self-propagating, selfgoverning, and self-supporting church (Rance 2009, 9) with the Three-Self formula demonstrated adequately in the AIC's. 
chance. Religion serves practical soteriological ends in Africa (Masega 1997, 195). ${ }^{36}$ Related to prayers for prosperity is the teaching of tithing and freewill offerings; when Christians are faithful in their tithing, God insulates them and their endeavours from 'devourers,' so that they can prosper in health and wealth (Asamoah-Gyadu 2013a, 89).

\section{Concluding remarks}

This article suggests that John G. Lake should be remembered and commemorated for his legacy in the form of the AFM of SA as well as the African Pentecostal churches ('spiritual churches', 'Spirit-type churches', 'independent African Pentecostal churches' or 'prophet-healing churches') constituting the majority of socalled African independent (or indigenous) churches (AICs).

The AFM commemorates Lake in at least three aspects that characterise the theological legacy of Lake. Lake's stand against racism eventually contributed to its four racially divided divisions becoming united in 1996 after a long and arduous journey. Lake's dream of a multiracial, united church was realised. A second aspect of Lake's theological legacy concerns his unrelenting missionary zeal leading to a strong emphasis on missionary work in the AFM. Thirdly, Lake's emphasis on the ministry of healing through faith in Jesus Christ is still important in a world filled with ill people.

African Pentecostal churches emerged as a radical expression of cultural resistance enabling Southern African blacks to mitigate the sufferings imposed by capitalism, colonialism and apartheid. African Pentecostal churches provided a dynamic Christianity that met African needs with a practice and theology of the Holy Spirit that is at the same time contextualised and biblical. In their emphasis on the power of the Spirit, African Pentecostals commemorate the most important element of the theological legacy of Lake. African Pentecostal churches also emphasise divine healing as the practical agency of divine force in the same manner as Lake did when he connected healing to the atonement. It is this message of liberation that makes the Pentecostal churches attractive to Africans. In Africa the most-powerful God is worshiped, and he manifests his presence through the Holy Spirit working in the church.

36 Cp. Cox's $(1995,11)$ remark that religion is an invaluable window into understanding human behaviour because people live according to patterns of value and meaning without which life would not make sense. African Pentecostal religion makes sense when viewed against the backdrop of the resilience of primal religious ideas even in the face of modernity, technology and scientific development (Asamoah-Gyandu 2013b, 139). 


\section{REFERENCES}

Althouse, P. 2009. Towards a Pentecostal ecclesiology: Participation in the missional life of the triune God. Unpublished paper presented at the $38^{\text {th }}$ annual meeting of the Society for Pentecostal Studies, 1-19.

Anderson, A.H. 1991. Moya: The Holy Spirit in an African context. Pretoria: Unisa.

Anderson, A.H. 1992. Bazalwane: African Pentecostals in South Africa. Pretoria: Unisa.

Anderson, A.H. 1997. African Pentecostal churches and concepts of power. Unpublished paper read at the Africa Forum, Council of Churches for Britain and Ireland, April 1997.

Anderson, A.H. 2000. Zion and Pentecost: The spirituality and experience of Pentecostals and Zionist/Apostolic churches in South Africa. African Initiatives in Christian Mission. Pretoria: University of South Africa.

Anderson, A.H. 2001. African Reformation: African initiated churches in the 20th century. Trenton, NJ: Africa World Press.

Anderson, A.H. 2012a. 'African Pentecostalism.” In Handbook of Pentecostal spirituality, 27-31, Stewart, A. (ed.). DeKalb: Northern Illinois University Press.

Anderson, A.H. 2012b. 'Keswick movement.' In Handbook of Pentecostal spirituality, 128-130, Stewart, A. (ed.). DeKalb: Northern Illinois University Press.

Anderson, A.H. 2012c. 'William Joseph Seymour.' In Handbook of Pentecostal spirituality, 186189, Stewart, A. (ed.). DeKalb: Northern Illinois University Press.

Anderson, R.M. 1979. Vision of the disinherited: The making of American Pentecostalism. Peabody: Hendrickson.

Anderson, R.S. 1986. Minding God's business. Grand Rapids: Eerdmans.

Asamoah-Gyadu, J.K. 2002. 'Pentecostalism in Africa and the changing face of Christian mission: Pentecostal/charismatic renewal movements in Ghana.' Mission Studies 19(2):14-39.

Asamoah-Gyadu, J.K. 2013a. Contemporary Pentecostal Christianity: Interpretations from an African context. Regnum studies in global Christianity. Eugene: WIPF \& STOCK.

Asamoah-Gyadu, J.K. 2013b. 'Pentecostalism and the influence of primal realities in Africa.' In The many faces of global Pentecostalism, 139-161, Hunter, H.D. and Ormerod, N. (ed.). Cleveland: CPT.

Asamoah-Gyadu, J.K. 2015. Sighs and signs of the Spirit: Ghanaian perspectives on Pentecostalism and renewal in Africa. Regnum Studies in Mission. Oxford: Regnum.

Baëta, C.G. 1962. Prophetism in Ghana. London: SCM.

Barnes, L.L. and Sered, S.S. (eds). 2005. Religion and healing in America. New York: Oxford University Press.

Barrett, D. 1998. 'A century of growth.' Christianity Today 42(16): 50-51.

Berglund, A.I. 1976. Zulu thought-patterns and symbolism. London: Hurst.

Blumhofer, E. 2006. 'Azusa Street revival.' Christian Century 123(5): 20-22.

Boesak, A.A. 1977. Farewell to innocence. Johannesburg: Ravan.

Botha, E. 2007. 'The New Reformation: The amazing rise of the Pentecostal-charismatic movement in the 20th century.' Studia Historiae Ecclesiasticae 33(1): 295-325. 
Burger, I.S.V.D.M. 1987. Die geskiedenis van die Apostoliese Geloof Sending van Suid-Afrika (1908-1958). Published D.D. dissertation, University of Pretoria. Johannesburg: Gospel Publishers.

Burger, I.S.V.D.M. 1997. 'A historical perspective on the origin of the Apostolic Faith Mission of South Africa.' In The reality of the Holy Spirit in the church: In honour of F.P. Möller, 175191, Gräbe, P.J. and Hattingh, W.J. (eds). Pretoria: J.L. van Schaik.

Burger, I. and Nel, M. 2008. The fire falls in Africa: A history of the Apostolic Faith Mission of South Africa. Vereeniging: Christian Art.

Burton, W.F.P. 1934. When God makes a pastor. London: Victory.

Cauchi, T. 2004. 'Charles Fox Parham (1873-1929).' Revival Library. http://www.revival-library. org/pensketches/am_pentecostals/parham.html (accessed 4 June 2015).

Chan, S. 2000. Pentecostal theology and the Christian spiritual tradition. JPTSup 21. Sheffield: Sheffield Academic Press.

Chappell, P.G. 1983. The divine healing movement in America. PhD. dissertation, Drew University.

Chappell, P.G. 1988. 'Healing movements.' In Dictionary of Pentecostal and charismatic movements, 353-374, Burgess, S., McGee, G. and Alexander, P. (eds). Grand Rapids: Zondervan.

Clark, M.S., Lederle, H.I. et al. 1989. What is distinctive about Pentecostal theology? Miscellanea specialia 1 Unisa. Pretoria: Sigma.

Cochrane, J.R. 1994. 'Christianity during a period of "national consolidation".' In A history of Christianity in South Africa, 200-250, Vol. 1, Hofmeyr, J.W. and Pillay, G.J. (eds). Pretoria: HAUM Tertiary.

Comaroff, J. 1985. Body of power, Spirit of resistance: The culture and history of a South African people. Chicago: University of Chicago Press.

Copeland, G. 1994. 'Foreword.' In John G. Lake: His life, his sermons, his boldness of faith, xiiixxx, Lake, J.G. Forth Worth: Kenneth Copeland Publications.

Cox, H. 1995. Fire from heaven: The rise of Pentecostal spirituality and the reshaping of religion in the twenty-first century. Reading, Mass: Addison-Wesley.

Cullis, C. 1983. Faith healing. Reprinted. Boston: Willard Tract Repository.

Dallimore, A. 1983. The life of Edward Irving: The fore-runner of the charismatic movement. Edinburgh: Banner of Truth Trust.

Daneel, M.L. 1971. Old and new in Southern Shona independent churches. Vol. 1. The Hague: Mouton.

Dayton, D. 1987. Theological roots of Pentecostalism. Lanham: Scarecrow.

De Wet, C.R. 1989. The Apostolic Faith Mission in Africa 1908-1980: A case study in church growth in a segregated society. PhD. dissertation, University of Cape Town.

Du Plessis, J. 1919. The life of Andrew Murray of South Africa. London: Marshall.

Editorial. 1906. Apostolic Faith. September 1906, 1.

Editorial, 1908. Pentecost. August 1908, 1.

Fletcher, J. 1820. Checks to Antinomianism. Vol. 3. New York: J. Souls and T. Mason. 
Friesen, A. 2009. 'The called out of the called out: Charles Parham's doctrine of Spirit baptism.' The Journal of the European Pentecostal Theological Association 29(1): 43-55.

Gabriel, A.K. 2012. 'Neo-Pentecostalism.' In Handbook of Pentecostal spirituality, 150-154, Stewart, A. (ed.). DeKalb: Northern Illinois University Press.

Gee, D. 1949. The Pentecostal movement: Including the story of the war years (1940-1947). London: Elim.

Goff, J.R. 1988. Fields white unto harvest: Charles F. Parham and the missionary origins of Pentecostalism. Fayetteville: University of Arkansas Press.

Haliburton, G. 1976. 'Edward Lion of Lesotho.' Mohlomi 1: 64-70.

Hammonds, R. 2009. The Pentecostal movement. Bloomington: AuthorHouse.

Harper, M. 2008. 'The waves keep coming in.' The Journal of the European Pentecostal Theological Association 28(2): 102-117.

Haywood, G.T. 1908. 'Baptized with the Holy Ghost and healed.' Bridegroom's Messenger December 1:3.

Hollenweger, W.J. 1972. The Pentecostals. London: SCM.

Hollenweger, W.J. 1974. Pentecostals between black and white. Belfast: Christian Journals.

Horn, J.N. 1989. From rags to riches: An analysis of the Faith movement and its relation to the classical Pentecostal movement. Pretoria: University of South Africa.

Jenkins, P. 2002. The next Christendom: The coming of global Christianity. New York: Oxford University Press.

Joubert, S. 2013. 'Not by order, nor by dialogue: The metanoetic presence of the kingdom of God in a fluid new world and church.' Acta Theologica 33(1): 114-134. DOI: http://dx.doi. org/10.4314/actat.v33i1.6

Kärkkäinen, V.M. 2005. 'Spirit, reconciliation and healing in the community: Missiological insights from Pentecostals.' International Review of Missions 94(372): 43-50.

Kelsey, M.T. 1964. Tongue speaking: An experiment in spiritual experience. London: Hodder \& Stoughton.

Klaus, B.D. 2006. 'Pentecostalism and mission.' Paper read at the American Society of Missiology, 17 June 2006, 1-18.

Kritzinger, J.N.J. 1988. Black theology: Challenge to mission. DTh. dissertation, University of South Africa.

Lake, J.G. 1960. 'Die koperslang.' Comforter 40(4): 17-18.

Lake, J.G. 1971. The new John G. Lake sermons. Edited by G. Lindsay. Dallas: Christ for the Nations.

Lake, J.G. 1981. Adventures in God. Tulsa: Harrison House.

Lake, J.G. 1994. John G. Lake: His life, his sermons, his boldness of faith, xiii-xxx. Forth Worth: Kenneth Copeland Publications.

Land, S.J. 1993. Pentecostal spirituality: A passion for the kingdom. Cleveland: CPT.

Latourette, K.S. 1975. A history of Christianity: Reformation to the present. Vol. II. Revised edition. New York: Harper \& Row. 
Liardon, R. 1996. God's generals: Why they succeeded and why some failed. New Kensington: Whitaker House.

Liardon, R. 2005. John G. Lake: The complete collection of his life teachings. New Kensington: Whitaker House.

Lindsay, G. (ed.) 1949. The John G. Lake sermons on dominion over demons, disease and death. Dallas: Christ for the nations.

Lindsay, G. 1972. John G. Lake, apostle to Africa. Dallas: Christ for the Nations.

Lindsay, G. (ed.) 1976. Spiritual hunger, the God-man and other sermons by John G. Lake. Dallas: Christ for the nations.

Lindsay, G. 1978. John G. Lake: God se gesant na Afrika. Braamfontein: AGS Drukkers.

Lord, A. 2005. Spirit shaped mission: A holistic charismatic missiology. Studies in Pentecostal and charismatic missions. Milton Keynes: Paternoster.

Lovett, L. 1975. 'Black origins of the Pentecostal movement.' In Aspects of Pentecostalcharismatic origins, 123-146, Synan, V. (ed.). Plainfield: Logos.

Lukhaimane, E.K. 1980. The Zion Christian Church of Ignatius Engenas Lekganyane, 1924 to 1948: An African Experiment with Christianity. MA.dissertation, University of the North.

Ma, W. 2013. 'A global shift of world Christianity and Pentecostalism.' In The many faces of global Pentecostalism, 62-70, Hunter, H.D. and Ormerod, N. (ed.). Cleveland: CPT.

MacRobert, I. 1988. The black roots and white racism of early Pentecostalism in the USA. Basingstoke:Macmillan.

Maimela, S.S. 1985. 'Salvation in African traditional religions.' Missionalia 13: 63-77.

Martin, D. 2002. Pentecostalism: The world their parish. Religion and modernity. Oxford: Blackwell.

Masega, L. 1997. African religion: The moral traditions of abundant life. Maryknoll: Orbis Books.

McClung, G. 2006. 'Pentecostals: The sequel. What will it take for this global phenomenon to stay vibrant for another 100 years?' Christianity Today 50(4): 30-36.

McGee, G.B. 2006. 'Taking the Logic "a little further": Late nineteenth-century references to the gift of tongues in mission-related literature and their influence on early Pentecostalism.' Asian Journal of Pentecostal Studies 9: 99-125.

McGee, G.B. 2007. 'Brought into the sphere of the supernatural: How speaking in tongues empowered early Pentecostals.' Encounter 4(1): 1-16. http://www.agts.edu/encounter/ articles/2007_fall/mcgee.htm (accessed 10 May 2015).

McQueen, L.R. 2009. Joel and the Spirit: The cry of a prophetic hermeneutic. Cleveland: CPT.

Mittelstadt, M.W. 2010. Reading Luke-Acts in the Pentecostal tradition. Cleveland: CPT.

Molobi, V. 2008. 'The marginalisation of women in the African Initiated Churches in South Africa.' Studia Historiae Ecclesiasticae XXXIV: 289-308. http://hdl.handle.net/10500/4529 (accessed 30 August 2015).

Molobi, V. 2014. 'Living in the townships: An appraisal of Pentecostal social ministry in Tshwane.' HTS Teologiese Studies/Theological Studies 70(3), Art. \#2791, 9 pages. http:// dx.doi.org/10.4102/hts.v70i3.2791 (accessed 30 August 2015). 
Molobi, V. and Chikane, F. 2008. An oral history of the South African Apostolic Faith Mission: A missing link of black historical discourse (1908-1960 onwards). Pretoria: C.B. Powell Centre, Unisa.

Morton, B. 2012. " "The devil who heals": Fraud and falsification in the evangelical career of John G. Lake, missionary to South Africa 1908-1913.' African Historical Review 44(2): 98-118.

Morton, B. 2014. 'Shembe and the early Zionists: A reappraisal.' New Contree 69: 71-92.

Myland, D.W. 1910. The Latter Rain covenant and Pentecostal power with testimonies of healings and baptism. Chicago: Evangel Publishing House.

Nel, M. 1996. 'Eva Stuart: Woman pioneer in the Pentecostal movement.' In Digging up our foremothers: Stories of women in Africa, 243-257, Landman, C. (ed.). Pretoria: Unisa Press.

Nel, M. 2005a. 'P.L. le Roux, Dutch Reformed missionary, Zionist preacher and leader of the Apostolic Faith Mission of South Africa, and the origin of some of the African Independent Churches in Southern Africa. Part 1.' Ned GerefTeologieseTydskrif 46(1-2): 200-208.

Nel, M. 2005b. 'P.L. le Roux, Dutch Reformed missionary, Zionist preacher and leader of the Apostolic Faith Mission of South Africa, and the origin of some of the African Independent Churches in Southern Africa. Part 2.' Studia Historiae Ecclesiasticae, XXXI(1): 127-143.

Nel, M. 2012. 'The process of unification of the AFM of SA.' Studia Historiae Ecclesiasticae 38(2): 121-141.

Oosthuizen, C.G, 1987. The birth of Christian Zionism in South Africa. Kwa-Dlangezwa: University of Zululand.

Parham, C.F. 1902. Kol kare bemidbar: A voice crying in the wilderness. Second edition. Kansas City: Charles Parham.

Parham, C.F. 2000. 'New religion “discovered" at "Stone's Folly" near Topeka,' Topeka Mail and Breeze, February 22, 1901, quoted in Martin, L. (ed.) The Topeka outpouring of 1901. Revised edition. Joplin, Mo.: Christian Life Books.

Parham, R.L. 1902. A voice crying in the wilderness. Joplin: Joplin Printing.

Parham, S. 1930. The life of Charles F. Parham: Founder of the Apostolic Faith Movement. Baxter Springs: Apostolic Faith Bible College.

Pete, R.M. 2015. 'The outpouring of the Holy Ghost at Azusa Street Mission: The impact of holiness preaching as taught by John Wesley and the outpouring of the Holy Ghost on racism.' http://www.revempete.us/research/holiness/azusa.html (accessed 18 May 2015).

Rance, D. 2009. Fulfilling the apostolic mandate in apostolic power: Seeking a Spirit-driven missiology and praxis. Unpublished paper presented at the $38^{\text {th }}$ annual meeting of the Society for Pentecostal Studies, 1-25.

Reidt, W.H. 1981. Jesus: God's way of healing and power to promote health. Featuring the miracle ministry of Dr John G. Lake. Tulsa: Harrison House.

Reidt, W. 1989. John G. Lake: A man without compromise. Tulsa: Harrison House.

Richie, T. 2007. 'Eschatological inclusivism: Exploring early Pentecostal theology of religions in Charles Fox Parham.' The Journal of the European Pentecostal Theological Association 27(2): 138-152.

Rodgers, D.J. 2003. Northern harvest: Pentecostalism in North Dakota. Bismarck: North Dakota District Council of the Assemblies of God. 
Satyavrata, I.M. 2005. 'Globalization of Pentecostalism.' In The encyclopedia of Pentecostal and charismatic Christianity, 218-223, Burgess, S.M. (ed.). London: Routledge.

Stronstad, R.J. 2012. 'Acts of the Apostles.' In Handbook of Pentecostal spirituality, 13-20, Stewart, A. (ed.). DeKalb: Northern Illinois University Press.

Sundkler, B.G.M. 1976. Zulu Zion and some Swazi Zionists. London: Oxford.

Susanto, J.L. and Theron, J. 2008. 'Compassion on people as a stimulus for the development of the church's healing ministry: Lessons from the lives of two Pentecostal pioneers.' Studia Historiae Ecclesiasticae 34(2): 169-184.

Synan, V. 1971. The holiness-Pentecostal movements in the United States. Grand Rapids: William B. Eerdmans.

Synan, V. 1997. The holiness-Pentecostal tradition: Charismatic movements in the twentieth century. Second edition. Grand Rapids: William B. Eerdmans.

Synan, V. 2001. The century of the Holy Spirit: 100 years of Pentecostal and charismatic renewal, 1901-2001. Nashville: Thomas Nelson.

Synan, V. 2006. 'The origins of the Pentecostal movement.' http:/www.oru.edu/library/special_ collections/holy_spirit_research_center/Pentecostal_history.php (accessed 2 May 2015).

Tan-Chow, M.L. 2013. Pentecostal theology for the twenty-first century: Engaging with multifaith Singapore. Ashgate New Critical Thinking in Religion, Theology and Biblical Studies. Surrey: Ashgate.

Tannenberg, W.M. 1999. 'The healer: Dr. John Graham Lake.' In John G. Lake: The complete collection of his life teachings, 10-23, Liardon, R. (ed.). Tulsa, Oklahoma: Albury.

Taylor, G.F. 1907. The Spirit and the bride. Falcon, N.C.: Taylor.

Tempels, P. 1959. Bantu philosophy. Paris: Présence Africaine.

Thompson, P.B. 1937. 'A Pentecostal outpouring of thirty-four years ago.' Pentecostal Evangel November 27:8.

Tickle, P. 2012. Emergence Christianity: What it is, where it is going, and why it matters. Grand Rapids: BakerBooks.

Turner, H.W. 1979. Religious innovation in Africa. Boston: G.K. Hall.

Ukpong, J.S. 1984. 'Current theology: The emergence of African theologies.' Theological Studies 45: 501-536

Van der Spuy, M.A. 1985. Die spanning tussen vryheid en formalisering ten opsigte van die liturgiese verskuiwinge binne die Apostoliese Geloof Sending van Suid-Afrika. MTh. dissertation, University of South Africa.

Wacker, G.A. 1999. 'Travail of a broken family: Radical evangelical responses to the emergence of Pentecostalism in America, 1906-16.' In Pentecostal currents in American Protestantism, 23-49, Blumhofer, E.L. et al. Urbana: University of Illinois Press.

Wacker, G. 2001. Heaven below: Early Pentecostals and American culture. Cambridge: Harvard University Press.

Walker, W. 1959. A history of the Christian church. Edinburgh: T \& T Clark.

Warfield, B.B. 1918. Counterfeit miracles. New York: Charles Scribner's Sons.

Warrington, K. 2005. Protestant Pentecostalism in Latin America: A study in the dynamics of missions. London: Associated University Press. 
Welch, C. 1972. Protestant thought in the nineteenth century. Vol. 1: 1799-1870. New Haven: Yale University Press.

Wenk, M. 2010. 'The church as sanctified community.' In Toward a Pentecostal ecclesiology: The church and the fivefold gospel, 105-135, Thomas, J.C. (ed.). Cleveland: CPT.

Wesley, J. [1766] 2012. A plain account of Christian perfection as believed and taught by the Reverend Mr John Wesley: A transcription in modern English. Asbury Theological Seminary Series in World Christian Revita. Lexington: Emeth.

Wesley, J. 1993. John Wesley's journal. Backhouse, R. (ed.). London: Hodder \& Stoughton.

West, N. 1894. John Wesley and premillenialism. Louisville: Pentecostal Publishing. 